\title{
Chromosome morphology of 12 species and one variety of Lachenalia and five species of closely related, allied genera (Liliaceae)
}

\author{
Shuichi Hamatani ${ }^{1,5}$, Katsuhiko Kondo ${ }^{2}$, Eiichi Kodaira ${ }^{3,4}$, and Hisao Ogawa ${ }^{3}$ \\ ${ }^{1}$ The Hiroshima Botanical Garden, 495 Kurashige 3, Saeki-ku, Hiroshima 731-5156, Japan; \\ ${ }^{2}$ Laboratory of Plant Chromosome and Gene Stock, Graduate School of Science, \\ Hiroshima University, 1-4-3 Kagamiyama, Higashi-Hiroshima 739-8526, Japan; \\ ${ }^{3}$ The Kyoto Botanical Garden, Shimogamo-nakaragi-cho, Sakyo-ku, Kyoto 606-0823, Japan; \\ ${ }^{4}$ Kyoto Herbal Garden, Takeda Pharmaceutial Company Limited, \\ 11, Ichijoji Takenouchi-Cho, Sakyo-Ku, Kyoto 606-8134, Japan \\ ${ }^{5}$ Author for correspondence (hamasyu@ma6.seikyou.ne.jp) \\ Received May 2, 2007; accepted June 25, 2007
}

\begin{abstract}
Somatic chromosomes in 12 species and one variety of Lachenalia and their closely related, two species of Massonia and three species of Polyxena, all in the Liliaceae, were studied. The resting nuclei of all of the taxa studied were commonly classified as the round prochromosome type. The mitotic prophase chromosomes of the taxa studied were commonly classified as the proximal type. However, their chromosome numbers varied from $2 \mathrm{n}=14,16,18,22,24,26$ to 28 . The chromosome numbers of $2 \mathrm{n}=14$ in Lachenalia algoensis, L. aloides 'Lutea', and L. longibracteata; $2 \mathrm{n}=18$ in L. latimerae; and $2 \mathrm{n}=28$ in Massonia pustulata and Polyxena longituba were reported here for the first time. The 13 taxa of Lachenalia studied were classified karyotypically into six groups. The two species of Massonia studied showed commonly the bimodal karyotype with four large chromosomes and the three species of Polyxena studied showed commonly the bimodal karyotype with three large chromosomes. The species of Massonia displayed much larger chromosomes at mitotic metaphase than those of the other two genera.
\end{abstract}

KEYWORDS: Lachenalia, Massonia, Polyxena, Liliaceae, Karyotypes

Lachenalia is an ornamentally valuable genus in the Liliaceae or sometimes placed in the Hyacinthaceae. The genus is endemic to the west of southern Africa and consists of approximately 115 species (Duncan 1998). Cladistic analysis uses detailed data on variations in the characteristics of flowers and other organs (Duncan 1988; Duncan et al. 2005).

Fifty-eight species and eight varieties in the genus have indicated the aneuploid series with chromosome numbers of $2 \mathrm{n}=10,12,14,16,17,18,21,22,23,24$, 26, 27, 28, 29, 30, 32, 40, 42, and 56 (e.g., Moffett 1936; Fernandes and Neves 1962; Gows 1964; Ornduff and Watters 1978; Nordenstam 1982; Johnson and Brandham 1997; Hamatani et al. 1998, 2004). However, a few taxa have reported karyotypes; e.g., 12 species of the genus were grouped by their karyotypes using microtome sectioning by Moffett (1936); correlationship between variation in chromosome number and presence of B-chromosomes was studied by Francis and Liebenberg (1990); 25 species and three varieties of the genus were classified into eight groups by their karyotypes (Hamatani et al. 1998, 2004). Those results were not consistent with the cladistic analysis by Duncan et al. (2005), which uses detailed data on variations in the characteristics of flowers and other organs. Moreover, it is hoped that the chromosomes of more species can be studied to validate the result of the cladistic analysis.

Massonia and Polyxena are close relatives of Lachenalia. Molecular studies using atpB and $\operatorname{trn} L-F$
DNA sequences and the shape of the seeds among those three genera were compared (emphasized) by Pfosser et al. (2003). However, chromosomes of Massonia and Polyxena have been scarcely studied; e.g., only a few species of the two genera have documented their chromosome numbers by Johnson and Brandham (1997).

The present study compared the karyotypes of the 12 species and one variety of Lachenalia, two species of Massonia, and three species of Polyxena.

\section{Materials And Methods}

The plants used were listed in Table 1. They were cultivated in the Hiroshima Botanical Garden and the Kyoto Botanical Garden. Root tips were harvested, pretreated in $2 \mathrm{mM} 8$-hydroxyquinoline at $20^{\circ} \mathrm{C}$ for $2 \mathrm{~h}$, and fixed and stored in $3: 1$ ethanol:acetic acid below $0{ }^{\circ} \mathrm{C}$ for a few days. They were macerated in a 1:1 mixture of $45 \%$ acetic acid and $1 \mathrm{~N}$ hydrochloric acid at about $60^{\circ} \mathrm{C}$ for $1.5 \mathrm{~min}$ and then stained and squashed with $2 \%$ aceto-orcein. Data on the resting nuclei and mitotic prophase chromosomes were classified according to Tanaka (1980), and mitotic metaphase chromosomes were classified according to Levan et al. (1964) and Hamatani et al. (2004).

\section{Results and Discussion}

The somatic chromosome numbers of the 12 species and 
Table 1. Chromosome numbers of 17 species and one variety of Lachenalia and allied genera studied

\begin{tabular}{|c|c|c|c|}
\hline Species and variety & $\begin{array}{l}\text { Chromosom } \\
\text { Present count }\end{array}$ & $\begin{array}{l}\text { number }(2 n) \\
\text { Previous count }\end{array}$ & Reference \\
\hline Lachenalia algoensis Schonl. & 14 & - & \\
\hline L. aloides (L.f.)Engl.'Lutea’' & 14 & - & \\
\hline L. juncifolia Bak. & 22 & 22 & Johnson and Brandham 1997 \\
\hline L. latifolia Tratt. & 24 & 24 & Johnson and Brandham 1997 \\
\hline L. latimerae W.F.Barker & 18 & - & \\
\hline L. longibracteata Phillips & 14 & - & \\
\hline L. muirii W.F.Barker & 14 & 14 & Johnson and Brandham 1997 \\
\hline L. namaquensis Schltr. ex W.F.Barker & 16 & 16 & Johnson and Brandham 1997 \\
\hline $\begin{array}{l}\text { L. orchioides (L.)Ait. } \\
\text { var. glaucina (Jacq.)W.F.Barker }\end{array}$ & 28 & 28 & Johnson and Brandham 1997 \\
\hline L. orchioides (L.)Ait. var. orchioides & 28 & $\begin{array}{c}16 \\
16,17 \\
28,29\end{array}$ & $\begin{array}{l}\text { de Wet } 1957 \\
\text { Moffett } 1936 \\
\text { Johnson and Brandham } 1997\end{array}$ \\
\hline L. pusilla Jacq. & 14 & 14 & $\begin{array}{l}\text { Johnson and Brandham } 1997 \\
\text { Hamatani, Hashimoto and Kondo } 1998\end{array}$ \\
\hline L. rosea Andrews & 14 & $\begin{array}{l}16 \\
14\end{array}$ & $\begin{array}{l}\text { Nordenstam } 1982 \\
\text { Johnson and Brandham } 1997\end{array}$ \\
\hline L. viridiflora W.F.Barker & 14 & 14 & $\begin{array}{l}\text { Nordenstam } 1982 \\
\text { Hancke and Liebenberg } 1990 \\
\text { Johnson and Brandham } 1997\end{array}$ \\
\hline Massonia depressa Houtt. & 26 & 26 & Johnson and Brandham 1997 \\
\hline M. pustulata Jacq. & 28 & 22 & Johnson and Brandham 1997 \\
\hline Polyxena ensifolia (Thunb.)Schönland & 26 & 24,26 & Johnson and Brandham 1997 \\
\hline P. longituba A.M. van der Merwe & 28 & - & \\
\hline $\begin{array}{l}\text { P. paucifolia (W.F.Barker) } \\
\text { A.M.van der Merwe et Manning. }\end{array}$ & 26 & 24,26 & Johnson and Brandham 1997 \\
\hline
\end{tabular}

Table 2. Karyotype of 17 species and one variety of Lachenalia and allied genera studied

\begin{tabular}{|c|c|c|c|}
\hline Species and variety & $\begin{array}{l}\text { Chromosome } \\
\text { number }(2 n)\end{array}$ & $\begin{array}{l}\text { Description by chromosome } \\
\text { length* }\end{array}$ & $\begin{array}{c}\text { Classification advocated by } \\
\text { Hamatani et al. (2004) }\end{array}$ \\
\hline Lachenalia algoensis & 14 & $6 \mathrm{~L}+8 \mathrm{~S}$ & Group 2 \\
\hline L. aloides 'Lutea' & 14 & $2 \mathrm{~L}+4 \mathrm{M}+8 \mathrm{~S}$ & Group 1 \\
\hline L. juncifolia & 22 & gradual decrease & Group 5 \\
\hline L. latifolia & 24 & gradual decrease & Group 5 \\
\hline L. latimerae & 18 & $3 \mathrm{~L}+15 \mathrm{~S}$ & New Group 9 \\
\hline L. longibracteata & 14 & gradual decrease & Group 3 \\
\hline L. muiri & 14 & $2 \mathrm{~L}+12 \mathrm{~S}$ & Group 1 \\
\hline L. namaquensis & 16 & $4 \mathrm{~L}+12 \mathrm{~S}$ & Group 4 \\
\hline L. orchioides var. glaucina & 28 & gradual decrease & Group 3 \\
\hline L. orchioides var. orchioides & 28 & gradual decrease & Group 3 \\
\hline L. pusilla & 14 & gradual decrease & Group 3 \\
\hline L. rosea & 14 & $6 \mathrm{~L}+8 \mathrm{~S}$ & Group 2 \\
\hline L. viridiflora & 14 & $6 \mathrm{~L}+8 \mathrm{~S}$ & Group 2 \\
\hline Massonia depressa & 26 & $4 \mathrm{~L}+22 \mathrm{~S}$ & - \\
\hline M. pustulata & 28 & $4 \mathrm{~L}+24 \mathrm{~S}$ & - \\
\hline Polyxena ensifolia & 26 & $3 \mathrm{~L}+23 \mathrm{~S}$ & - \\
\hline P. longituba & 28 & $3 \mathrm{~L}+25 \mathrm{~S}$ & - \\
\hline P. paucifolia & 26 & $3 \mathrm{~L}+23 \mathrm{~S}$ & - \\
\hline
\end{tabular}

* "L" means "large", "M" means "medium" and "S" means "small", relatively. 


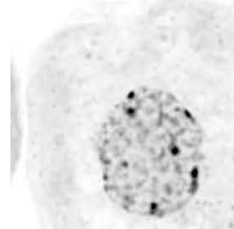

A
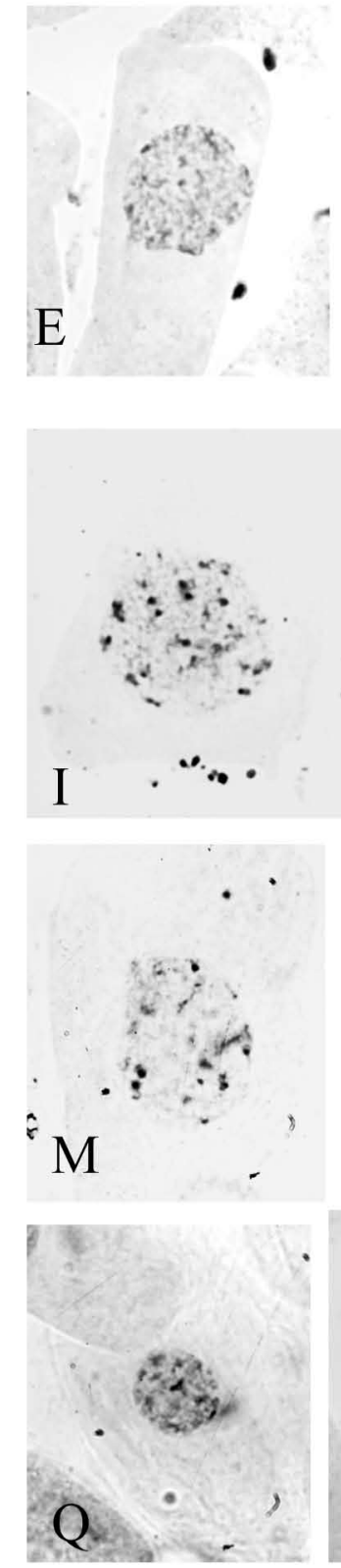

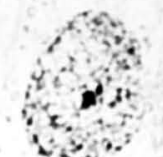

$\mathrm{B}$

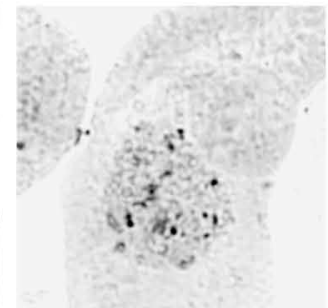

$\mathrm{F}$
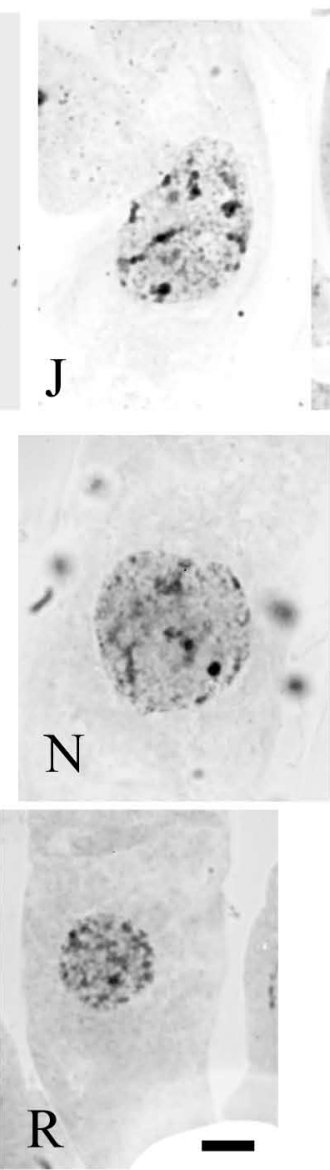

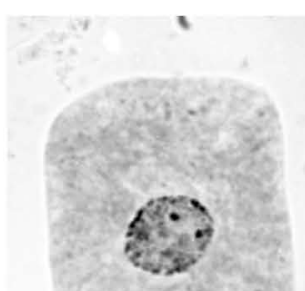

$\mathrm{C}$

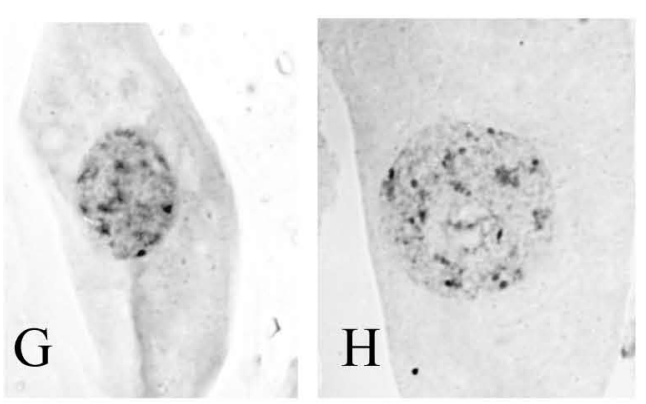

K
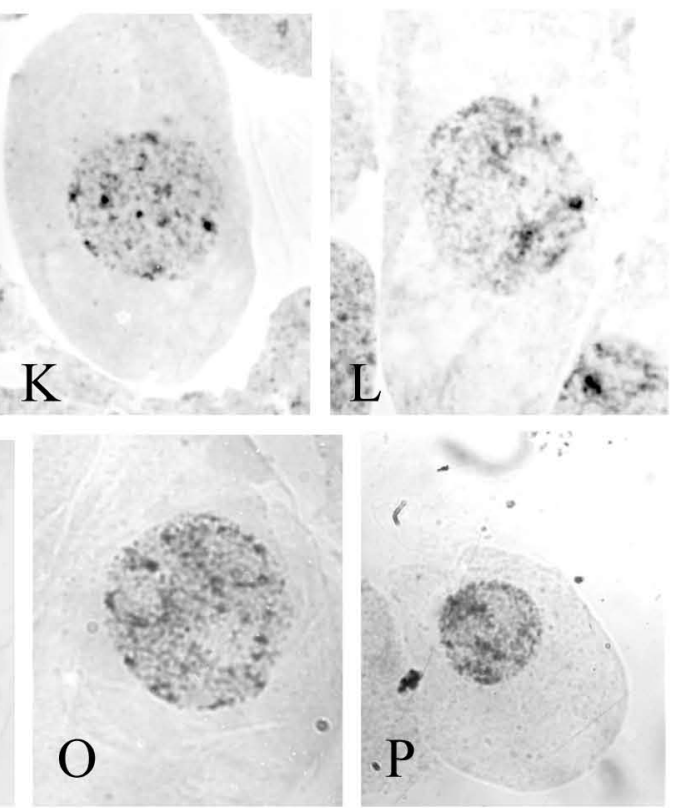

Fig. 1. Somatic chromosomes at resting stage in Lachenalia, Massonia, and Polyxena studied. A. Lachenalia algoensis, B. L. aloides 'Lutea', C. L. juncifolia, D. L. latifolia, E. L. latimerae, F. L. longibracteata, G. L. muirii, H. L. namaquenis, I. L. orchioides var. glaucina, J. L. orchioides var. orchioides, K. L. pusilla, L. L. rosea, M. L. viridiflora, N. Massonia depressa, O. M. pustulata, P. Polyxena ensifolia, Q. P. odorata, R. P. paucifolia. Bar $=5 \mu \mathrm{m}$. 

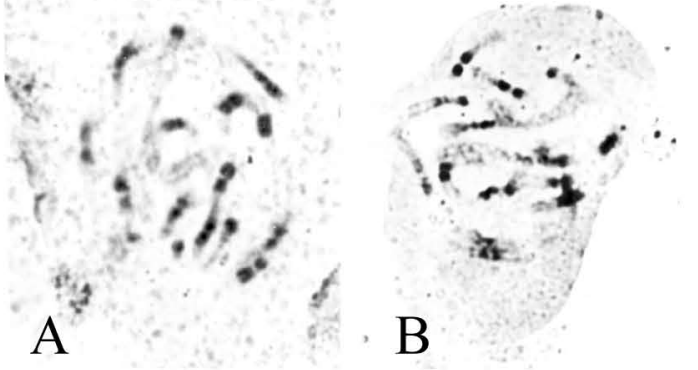

B

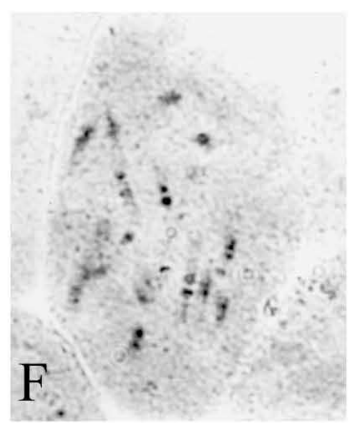

$\mathrm{E}$
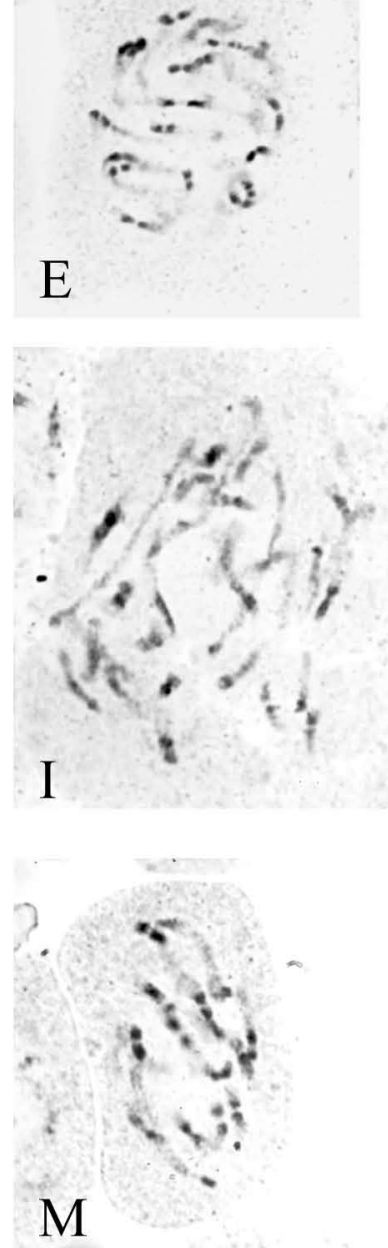
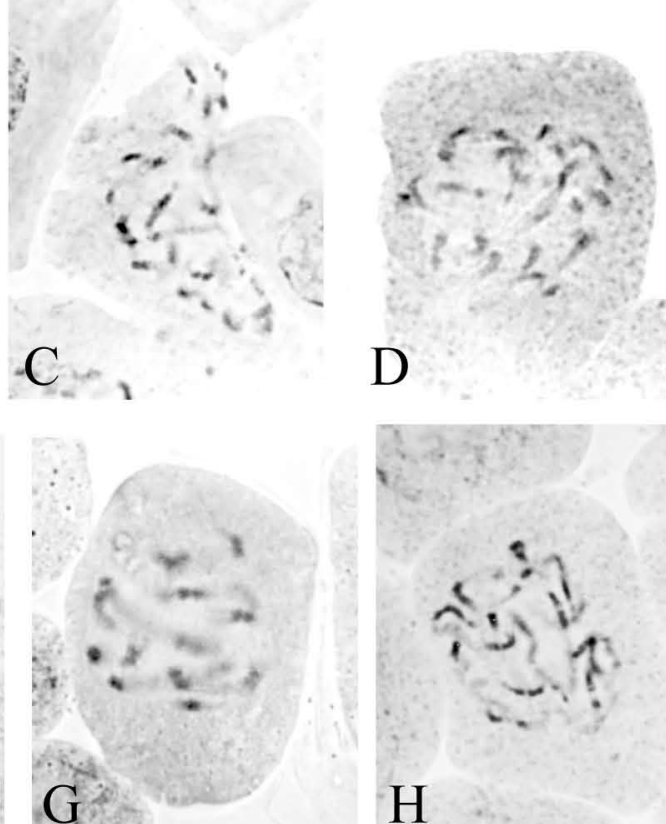

$\mathrm{D}$
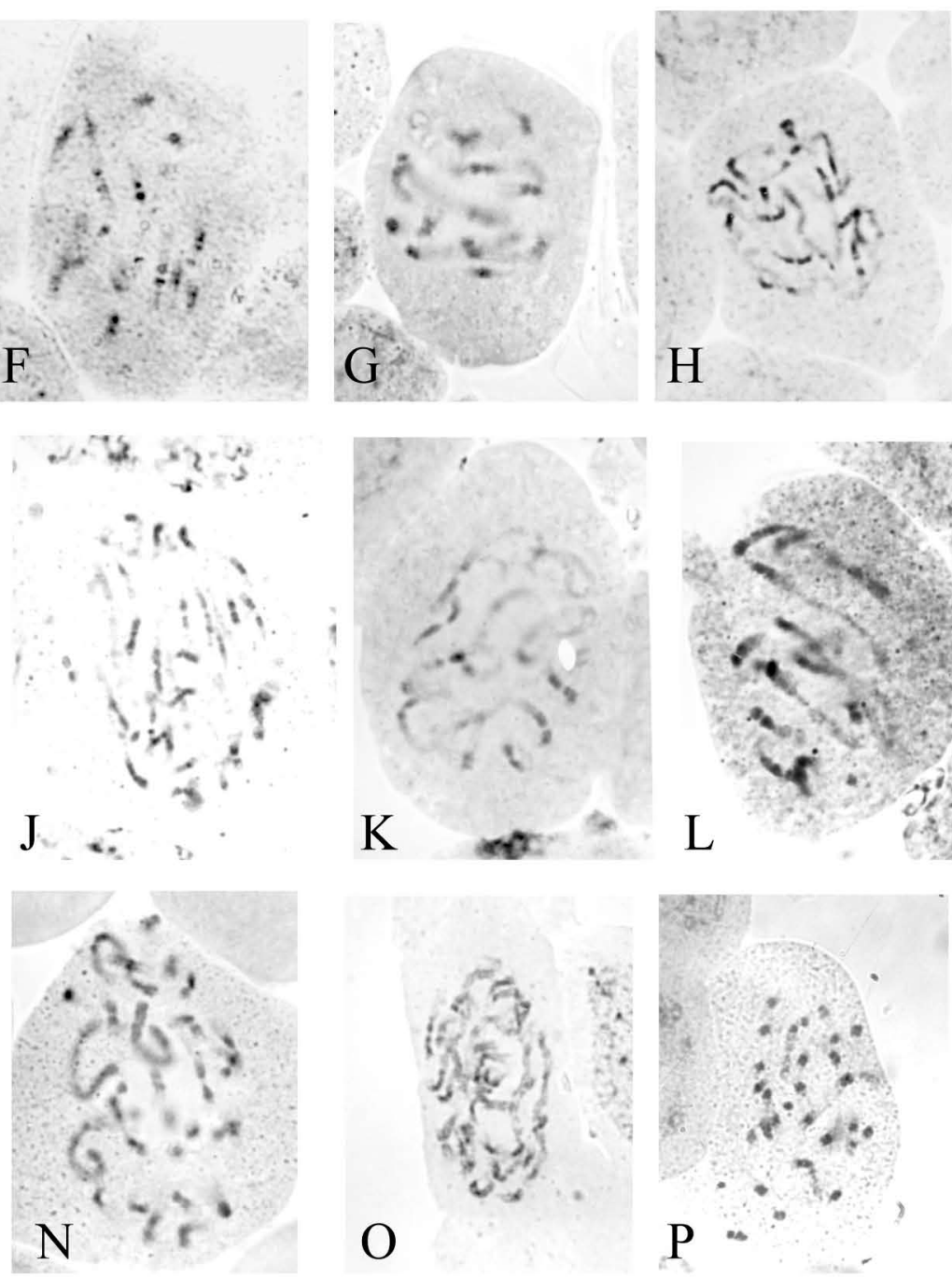

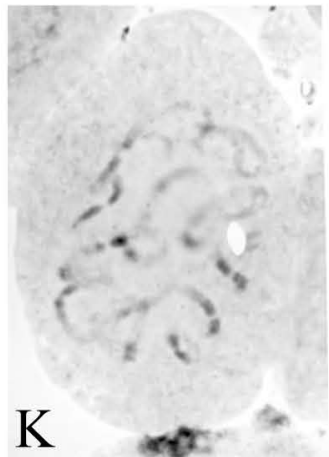

$\mathrm{L}$

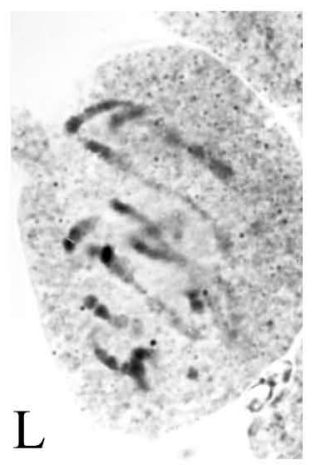

$\mathrm{O}$

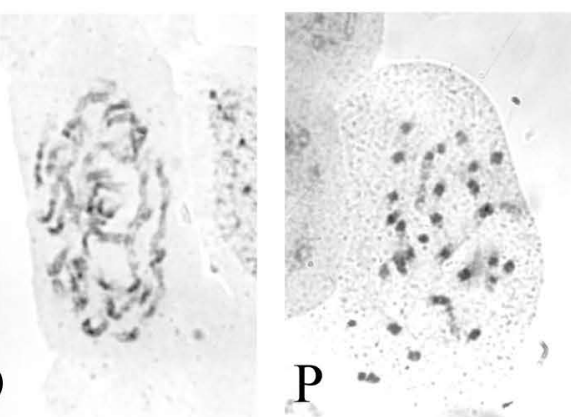

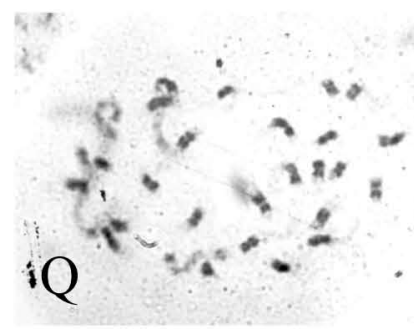

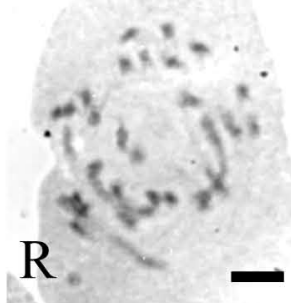

Fig. 2. Somatic chromosomes at mitotic prophase in Lachenalia, Massonia, and Polyxena studied. A. Lachenalia algoensis, B. L. aloides 'Lutea', C. L. juncifolia, D. L. latifolia, E. L. latimerae, F. L. longibracteata, G. L. muirii, H. L. namaquenis, I. L. orchioides var. glaucina,

J. L. orchioides var. orchioides, K. L. pusilla, L. L. rosea, M. L. viridiflora, N. Massonia depressa, O. M. pustulata, P. Polyxena ensifolia, Q. P. odorata, R. P. paucifolia. Bar $=5 \mu \mathrm{m}$. 

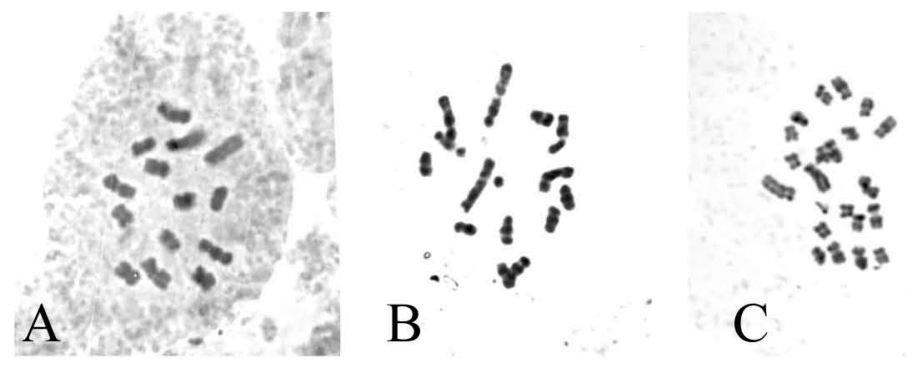

B

$\mathrm{C}$
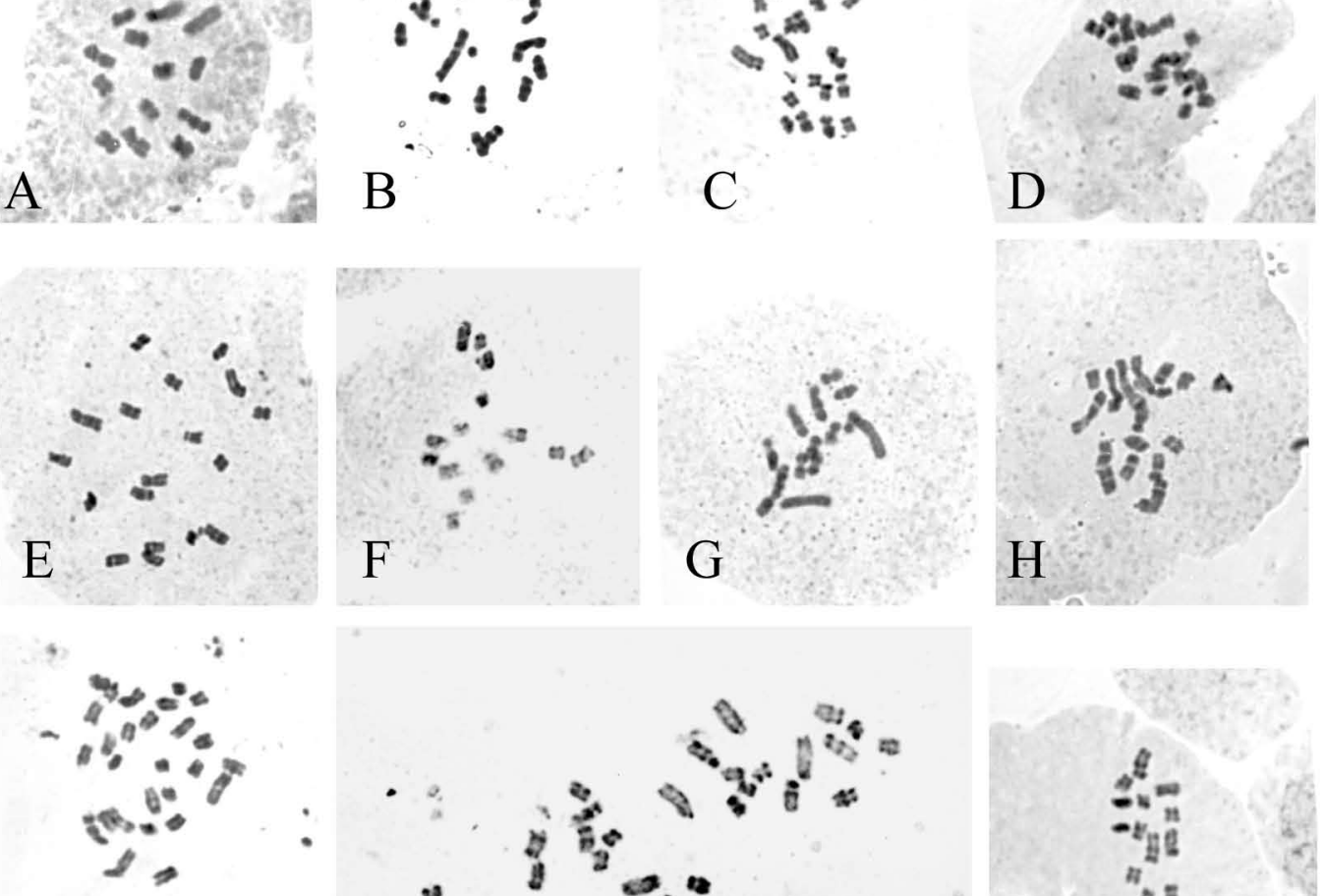

I 6.
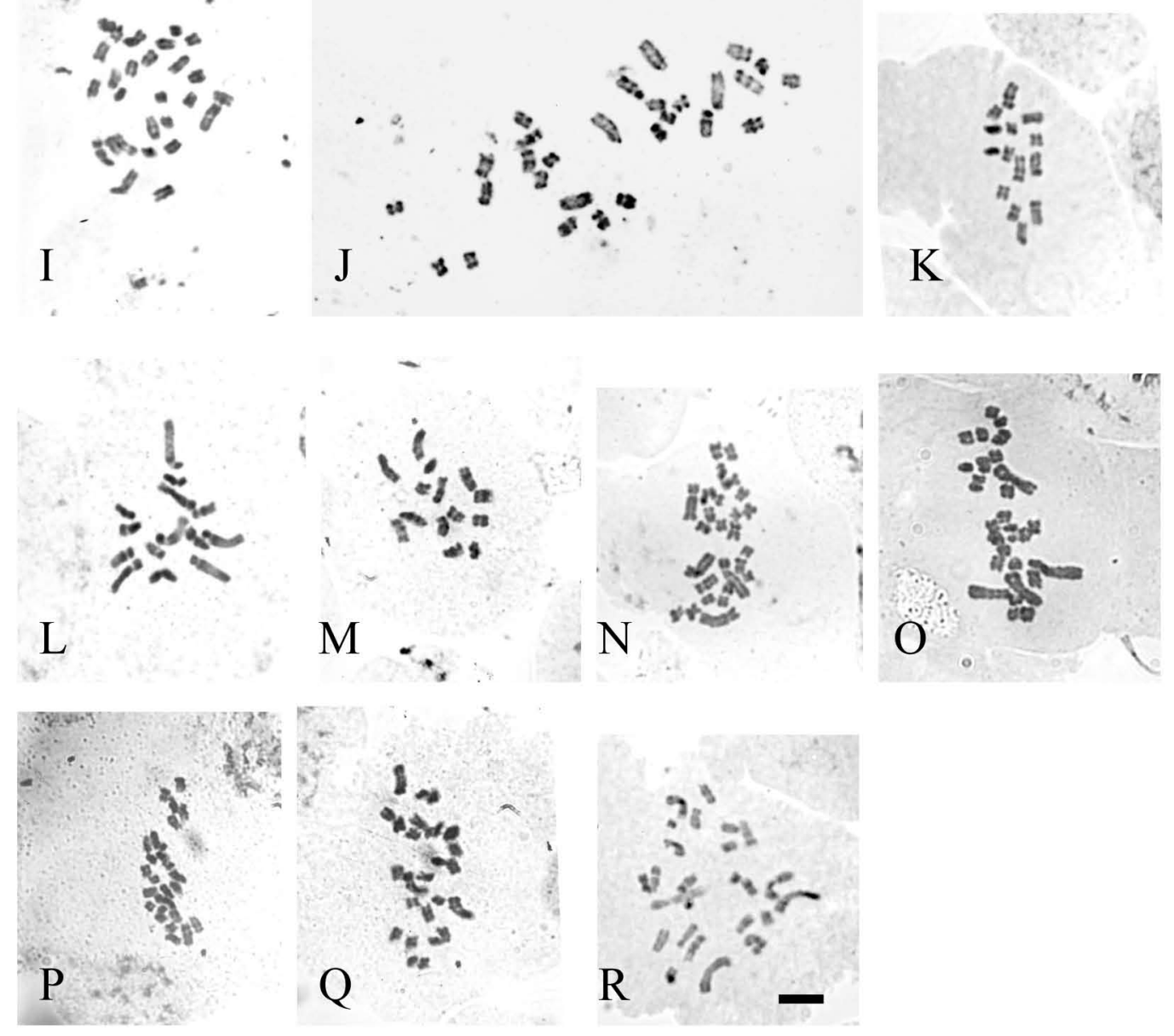

Fig. 3. Somatic chrmosomes at mitotic metaphase in Lachenalia, Massonia, and Polyxena studied.

A. Lachenalia algoensis, B. L. aloides 'Lutea', C. L. juncifolia, D. L. latifolia, E. L. latimerae,

F. L. longibracteata, G. L. muirii, H. L. namaquenis, I. L. orchioides var. glaucina,

J. L. orchioides var. orchioides, K. L. pusilla, L. L. rosea, M. L. viridiflora, N. Massonia depressa, O. M. pustulata, P. Polyxena ensifolia, Q. P. odorata, R. P. paucifolia. Bar $=5 \mu \mathrm{m}$. 


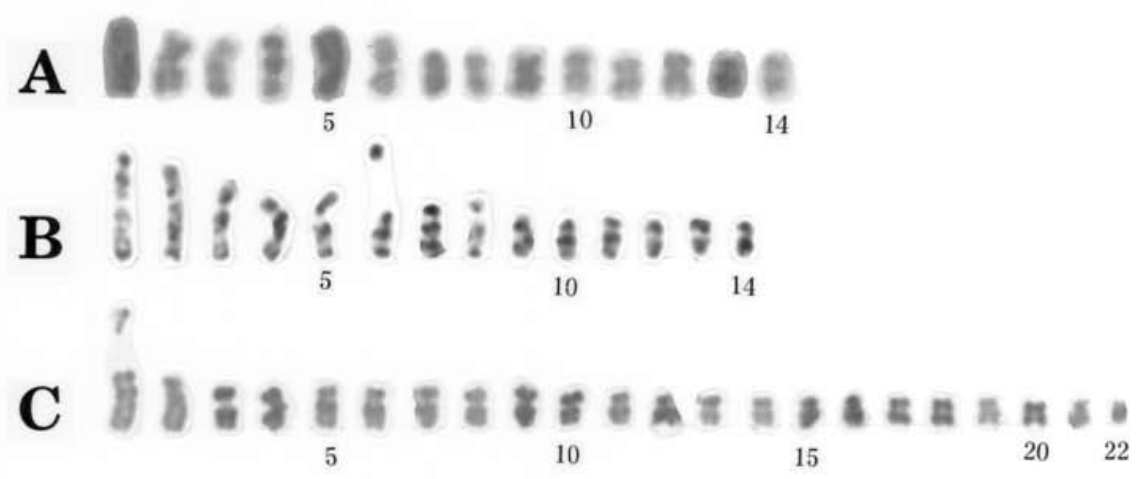

D

E

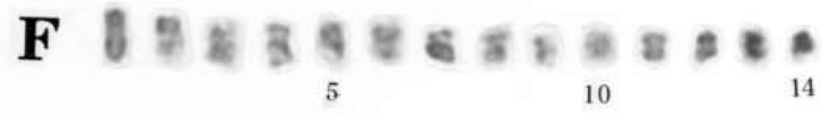

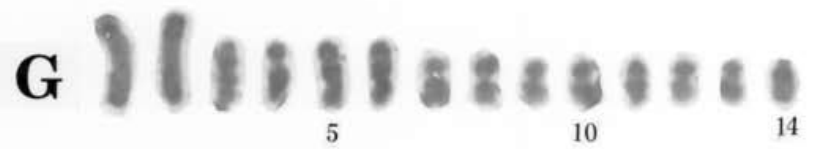

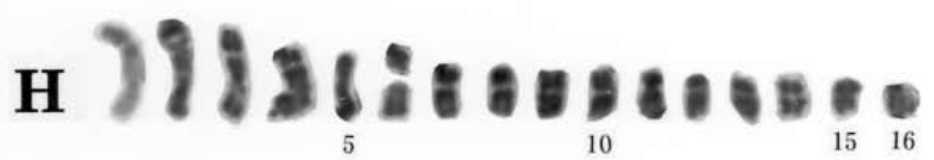

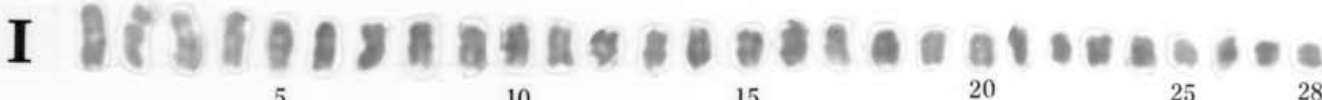

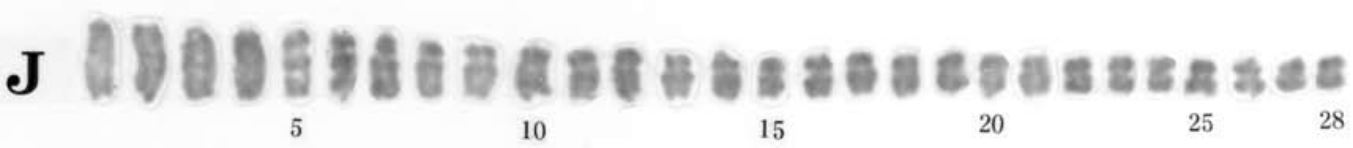

$\mathbf{K}$ औู้

Fig. 4. Karyotypes in Lachenalia, Massonia, and Polyxena studied.

A. Lachenalia algoensis, B. L. aloides 'Lutea', C L. juncifolia, D. L. latifolia, E. L. latimerae,

F. L. longibracteata, G. L. muirii, H. L. namaquenis, I. L. orchioides var. glaucina,

J. L. orchioides var. orchioides, K. L. pusilla, L. L. rosea, M. L. viridiflora, N. Massonia depressa,

O. M. pustulata, P. Polyxena ensifolia, Q. P. odorata, R. P. paucifolia. Bars $=5 \mu \mathrm{m}$.

one variety of Lachenalia, two species of Massonia and three species of Polyxena studied were shown in Table 1. Resting and mitotic prophase and metaphase chromosomes were shown in Figs. 1-3. Their karyotypes are shown in Fig. 4.

The resting nuclei of the 18 taxa studied were of the round prochromosome type (Fig. 1). The mitotic prophase chromosomes of the taxa were of the proximal type (Fig. 2).
The chromosome number of $2 \mathrm{n}=14$ was found in Lachenalia algoensis, L. aloides 'Lutea' and $L$. longibracteata; the chromosome number of $2 n=18$ was found in L. latimerae; the chromosome number of $2 n=26$ was found in Polyxena paucifolia; and the chromosome number of $2 \mathrm{n}=28$ was found in $P$. longituba. They were all reported here for the first time. The chromosome number of $2 \mathrm{n}=28$ in Massonia pustulata given here was different from the previous count by Johnson and 


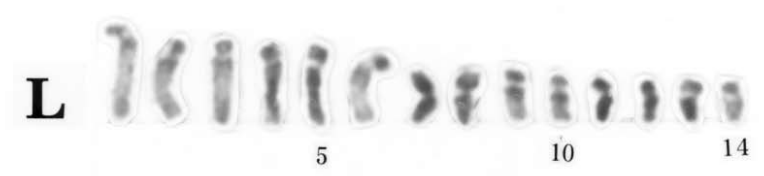

M If

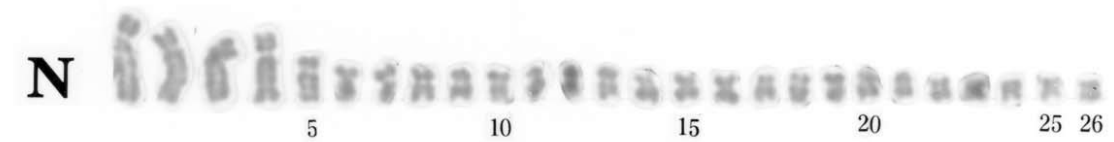

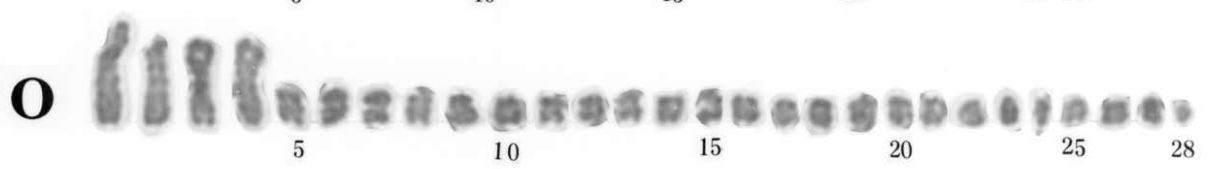
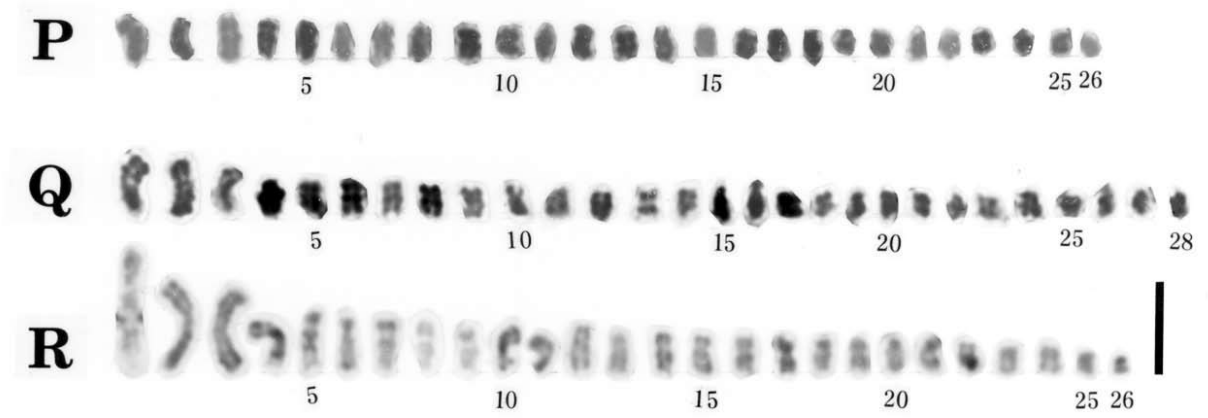

Fig. 4. Continued.

Brandham (1997). The chromosome numbers of those of the other 11 taxa studied verified the previous counts. The chromosome numbers of $L$. orchioides var. orchioides was previously reported to be $2 \mathrm{n}=16$ by de Wet (1957), $2 \mathrm{n}=16$ and 17 by Moffett (1936), $2 \mathrm{n}=28$ and 29 by Johnson and Brandham (1997). Thus, the chromosome count obtained in the present study supported those reported by Johnson and Brandham (1997).

The karyotypes of the taxa studied were described in Table 2. The 12 species and one variety of Lachenalia studied were classified into six groups according to the karyotype system of Hamatani et al. (2004). Lachenaria aloides 'Lutea' and L. muirii $(2 \mathrm{n}=14)$ showed a bimodal karyotype with two large-size chromosomes and 12 small-size chromosomes, and thus, were classified as the Group 1. It was suggested that the 12 small-size chromosomes of $L$. aloides 'Lutea' might be divided from four medium-size chromosomes and eight smallsize chromosomes. Lachenaria algoensis, L. rosea, and L. viridiflora $(2 \mathrm{n}=14)$ showed a bimodal karyotype with six large-size chromosomes and eight small-size chromosomes, and were classified as the Group 2. In the karyotypes of L. longibracteata and L. pusilla $(2 \mathrm{n}=14)$, the chromosomes showed a gradual decrease in size from the largest to the smallest chromosomes. Lachenaria pusilla was previously described to have the bimodal karyotype which was classified as the Group 2 of the karyotype system of Hamatani et al. (1998). However, the present strain of the species showed a monomodal karyotype of a gradual decrease in size from the largest to the smallest chromosomes. Additionally, the karyotypes of L. longibracteata and L. pusilla had commonly smaller chromosomes than the other species did. They were classified as the Group 3 (gradual decrease, $2 n=14$ and 42 with $x=7$ ). Since the karyotypes of $L$. orchioides var. glaucina $(2 \mathrm{n}=28)$ and L. orchioides var. orchioides $(2 \mathrm{n}=28)$ showed a gradual decrease in size from the largest to the smallest chromosomes (monomodal) and had the basic chromosome number of $\mathrm{x}=7$, these two taxa could also be classified in the Group 3. Lachenaria namaquensis $(2 \mathrm{n}=16)$ could be classified in the Group 4, since the species showed a bimodal karyotype with four large chromosomes and the other 12 small chromosomes. The karyotypes of L. juncifolia $(2 \mathrm{n}$ $=22)$ and L. latifolia $(2 \mathrm{n}=24)$ shown commonly gradual decrease in size from the largest to the smallest chromosomes were classified in the Group 5. The karyotype system of Hamatani et al. (2004) suggested to include another three groups in addition to the above five groups mentioned: The Group 6 was characterized by a bi-modal karyotype with two large chromosomes and the chromosome number of $2 n=22$, or that with four large chromosomes and the chromosome number of $2 n=44$; the Group 7 was characterized by a bimodal karyotype 
with three large chromosomes $(2 \mathrm{n}=22)$; and the Group 8 was characterized by a bimodal karyotype with two large chromosomes $(2 n=12)$. Thus, the monomodal karyotype of L. latimerae $(2 \mathrm{n}=18)$ shown a gradual decrease in size from the largest to the smallest chromosomes was regarded to have the basic chromosome number of $x=9$ and did not belong to any of the above eight groups. Thus, the karyotype of L. latimerae might organize another new Group 9.

Johnson and Brandham (1997) stated that the basic chromosome numbers of Lachenaria would be $\mathrm{x}=5,6,7$, $8,9,10,11,13$, and 15 and the most frequently occurred, basic chromosome numbers of $\mathrm{x}=7$ and 8 . Our present and past papers (Hamatani et al. 1998, 2004) also suggested that the most frequent, basic chromosome numbers were $x=7$ and 8 . The basic chromosome numbers of $\mathrm{x}=7$ and 8 in Lachenaria might contribute satisfactory speciation in the genus.

Lachenaria aloides 'Lutea' which had the bimodal karyotype with two large chromosomes could be placed in the Group 1. However, another strain of the taxon showed the trimodal karyotype of four medium-size chromosomes, two large-size chromosomes and eight small-size chromosomes. It might be is a complex type of tri-modality with a gradual decrease in size from the largest to the smallest chromosomes of Group 3 . Lachenaria longibracteata was also placed in the Group 3 that showed the karyotype of a gradual decrease in chromosome size from the largest to the smallest chromosomes but another strain of the species may also be placed in the Group 2 that showed bimodal karyotype with six large chromosomes. Many more study may deposit more diversity of karyotypes to make complex groupings of the Groups 1-3.

Lachenaria latimerae had three large chromosomes; two could form a pair but were different in arm ratio from the other one which had a satellite. Thus, this species might be originated from hybridization.

It is difficult to speculate the mutual relationships among the species that have the basic chromosome number of $x=7$, those that have the basic chromosome number of $\mathrm{x}=8$, and those that have the basic chromosome numbers other than $\mathrm{x}=7$ and 8 .

Massonia depressa showed the chromosome number of $2 \mathrm{n}=26$, and M. pustulata showed the chromosome number of $2 n=28$. The strains studied in the two species had commonly bimodal karyotype with four large chromosomes. The four large chromosomes in the karyotype of $M$. depressa were submedian-centromeric, while those of $M$. pustulata were median-centromeric. In contrast, small chromosomes of the karyotypes studied in the two species were commonly either mediancentromeric or submedian-centromeric.

Polyxena ensifolia and P. paucifolia showed the chromosome number of $2 \mathrm{n}=26$, and $P$. longituba showed the chromosome number of $2 n=28$. The strains studied in the three species had commonly bimodal karyotype with three large chromosomes. The karyotypes in each of the three species in Polyxena studied were different from each other and those in Massonia. Differences in size between the large and the small chromosomes in Polyxena were less than those in Massonia. One of the three large chromosomes common to the the strains studied in the three species in Polyxena displayed particularly large arm ratios. Thus, the strains studied in the three species of Polyxena might be originated from hybridization.

The karyotypes in the strains studied in Polyxena were much more similar to those in Lachenalia than those in Massonia with respect to sizes of large and small chromosomes. This conclusion supports the molecular phylogenetic relationships using atpB and $t r n L-F$ DNA sequences by Pfosser et al. (2003) .

ACKNOWLEDGMeNT. We thank Mr. Graham Duncan, Kirstenbosch Botanical Gardens for identifying species of Lachenalia and Massonia.

\section{Literature Cited}

Duncan, G. D. 1988. The Lachenalia handbook. In: J.N.Eloff, Ed., Ann. Kirstenbosch Bot. Gard. 17: 1-69.

Duncan, G. D. 1998. Notes on the genus Lachenalia. Herbertia 53: 40-48.

Duncan, G. D., Edwards, T. J. and Mitchell, A. 2005. Character variation and a cladistic analysis of the genus Lachenalia Jacq.f.ex Murray (Hyacinthaceae). Acta Hort. 673: 113-120.

Fernandes, A. and Neves, J. B. 1962. Sur la caryologie de quelques Monocotyledones africaines. Compt. Rend. de la IV-e Reunion Pleniere de l'Assoc. pour l'Etude Taxinomique de la Flore d'Afrique Tropicale. Lisboa: 439-463.

Francis, L. H. and Liebenberg, H. 1990. B-chromosomes in some Lachenalia species and hybrids. S. Afr. Journ. Bot. 56(6): 659-664.

Gouws, J. B. 1964. Cytological studies in the genus Lachenalia Jacq. Ann. Univ. Coll. Western Cape 2: 1-7.

Hamatani, S., Hasimoto, K. and Kondo, K. 1998. A comparison of somatic chromosomes at metaphase in Lachenalia (Liliaceae). Chrom. Sci. 2: 21-25.

Hamatani, S., Ishida, G., Hashimoto, K. and Kondo, K. 2004. A chromosome study in ten species of Lachenalia (Liliaceae). Chrom. Sci. 8: 55-61.

Johnson, M. A. T. and Brandham, P. E. 1997. New chromosome numbers in petaloid monocotyledons and in other miscellaneous angiosperms. Kew Bull. 52(1): 121-138.

Levan, A., Fredga, C. and Sandberg, A. A. 1964. Nomenclature of centromeric position on chromosomes. Heredetias 52: 201-220.

Nordenstam, B. 1982. Chromosome numbers of southern African plants: 2. Journ. S. African Bot. 48: 273-275.

Ornduff, R. and Watters, P. J. 1978. Chromosome numbers in Lachenalia (Liliaceae). Jour. S. African Bot. 48: 273-275.

Pfosser, M., Wetschnig, W., Ungar, S. and Prenner, G. 2003. Phylogenetic relationsips among genera of Massonieae (Hyacinthaceae) inferred from plastid DNA and seed morphology. J. Plant Res. 116: 115-132.

Tanaka, R. 1980. The karyotype. (in Japanese). In Kihara, H. (ed.), Plant Genetics 1: 335-358. Shokabo Co., Tokyo. 